\title{
Cyanogenic Glycoside Levels in Saskatoon Serviceberry
}

\author{
W. MAJAK, D.A. QUINTON, AND K. BROERSMA
}

\begin{abstract}
The concentration of prunasin, the cyanogenic glycoside in Saskatoon serviceberry, was determined in leaves and twigs over a 12 month period. Eight shrubs were monitored, three of which were located in the ponderosa pine zone and the remainder in the Douglasfir zone. Qualitative tests indicated that the cyanide potential of serviceberry persisted continuously at all the experimental sites in both leaves and twigs. Quantitative analyses showed that prunasin levels in twigs were substantially higher in current year's growth as compared to previous year's growth. The highest prunasin levels were obtained in new growth of leaves and twigs following initiation and and this potentially hazardous period for browsers is described. Shrubs yielded lower prunasin levels when they were associated with ground water indicator species.
\end{abstract}

Saskatoon serviceberry (Amelanchier alnifolia Nutt.) (Hitchcock and Cronquist 1976) has long been recognized as an important if not preferred browse for rangeland livestock and wildlife (Plummer et al. 1968). The proportion of serviceberry in the diet of free-ranging mule deer (Odocoileus hemionus hemionus) for example, varies from low to moderate (Willms et al. 1976; Kufeld et al. 1973), and in the British Columbia Interior, where the shrub is distributed widely, field observations indicate heavy utilization by range cattle ${ }^{1}$. Although the toxicity of chokecherry (Prunus Virginiana) is well known (Garner 1967; Radeleff 1970), only recently was the closely related serviceberry implicated as a poisonous plant (Majak et al. 1978). We identified the toxic principle in serviceberry as the cyanogenic glycoside prunasin (Majak et al. 1978) and subsequently confirmed that the cyanogenic properties of chokeberry were attributable to the same compound ${ }^{2}$.

One half $\mathrm{g}$ of prunasin can produce $46 \mathrm{mg}$ of hydrogen cyanide $(\mathrm{HCN})$, and for grazing animals daily doses in excess of $50 \mathrm{mg} \mathrm{HCN} / \mathrm{kg}$ body weight are considered to be dangerous (Radeleff 1970). Through the action of endogenous enzymes, the HCN can be liberated in either the plant or the animal. In plants this can occur as a result of cellular injury (frost) in which degradative enzymes are brought into contact with glycosides which appear to be isolated in vacuoles (Saunders and Conn 1978). In animals this occurs through the catalytic action of ingested plant tissue enzymes and rumen microbial enzymes (James et. al. 1975; Conn 1978).

The present study was designed to reveal the cyanide potential of serviceberry. To achieve this goal, prunasin concentrations were monitored in different parts of the

\footnotetext{
Authors are plant biochemist, range ecologist, and agronomist, Research Station, Agriculture Canada, Kamloops, British Columbia. This report is contribution No. 282.

The technical assistance of Ruth McDiarmid and Lynne Clark is gratefully acknowledged.

Contribution No. 282.

Manuscript received December 18, 1978.

'Quinton. D.A. 1978. unpublished results.

${ }^{2}$ Majak, W. 1978. unpublished results.
}

shrub collected from various locations and over a 12 month period. The results will point to some of the risk factors involved when serviceberry is browsed by ruminants.

\section{Materials and Methods}

\section{Sample Collection}

Serviceberry samples were collected at eight sites along a $30-\mathrm{km}$ stretch on the west side of the North Thompson River Valley between Kamloops (elev. $339 \mathrm{~m}$ ) and McLure (elev. $373 \mathrm{~m}$ ), B.C. The sites were numbered in sequence from 1 to 8 beginning with the most northerly site at McLure. At each site during September 1977 to August 1978, the same shrub was sampled at 4 to 6-week intervals. At least five terminal ends of branches containing current and previous year's growth were snipped from each shrub and transported in plastic bags on dry ice. In a coldroom, the leaves were separated from the twigs, and these were snipped at the bud scars into current and previous year's growth. Composite shrub samples (approximately $10 \mathrm{~g}$ fresh weight) representing each part from each site were stored in plastic bags at $-20^{\circ}$.

\section{Prunasin Determination}

Frozen shrub samples were chilled on dry ice for an hour and then ground in powdered dry ice using a 20-mesh screen in an Intermediate Wiley mill. Excess dry ice in the sample was allowed to dissipate at $-20^{\circ}$ over a period of 24 to 48 hours. To prevent losses of $\mathrm{HCN}$ through the action of endogenous enzymes it was essential to maintain the freshly ground sample in a frozen state and to load the incubation flasks as quickly as possible. Therefore the ground sample was transported on dry ice to a coldroom $\left(4^{\circ} \mathrm{C}\right)$ where a subsample $(100 \mathrm{mg})$ was introduced into the main compartment of a $25-\mathrm{ml}$ Erlenmeyer flask containing a centre well (Secor et al. 1976). Phosphate buffer (0.1 M, pH 6.4), $2 \mathrm{ml}$, and $\beta$ glucosidase (almond emulsin) solution $(0.1 \%$ in $0.1 \mathrm{M}$ phosphate buffer, pH 6.4), $1.0 \mathrm{ml}$, were added immediately to the main compartment, $0.4 \mathrm{ml}$. $\mathrm{N} \mathrm{NaOH}$ was added to the centre well and the flask was sealed and incubated at $35^{\circ} \mathrm{C}$ for 16 hours. At that time the $\mathrm{NaOH}$ from the centre well was removed, adjusted to a volume of $1 \mathrm{ml}$ and duplicate aliquots were analyzed for cyanide by the colorimetric procedure of Aldridge (1944). Since there was close agreement between replicate incubations $(< \pm 5 \%$ variation with respect to duplicate cyanide determinations), a single incubation of each sample was considered sufficient. Commercially available amygdalin standards $((R)$-mandelonitrile$\beta$-D-glucosido-6-D- $\beta$-glucoside) were incubated concomitantly and standard curves were derived for $\mathrm{HCN}$ enzymatically released from amygdalin. Prunasin ((R)-mandelonitrile- $\beta$-D-glucoside) concentrations were calculated from the HCN determinations by multiplying by the molecular weight ratio, $295 / 27$. Subsamples of the frozen, ground material were used for duplicate dry weight determinations which varied by $< \pm 2 \%$.

\section{Statistical Analysis}

The prunasin values were examined in two groups representing the Fall to Winter interval (September 1977 to April 1978) and the Spring to Summer interval (May. 1978 to August 1978). Analysis of variance was conducted for each group with prunasin concentration (percent dry weight) as the dependent variable and site (A). 
shrub part (B) and collection date (C) as the three factors. During the Fall-Winter interval shrub parts consisted of twig segments representing current and previous year's growth. Spring-Summer shrub parts included leaves, and twig segments representing new and previous year's growth. Two observations per cell were derived from duplicate prunasin determinations and the underestimate of variation per cell was reduced by using the $A B C$ interaction mean square term as the denomintor in calculating $F$ values. The FallWinter experiment consisted of 112 cells representing eight sites, seven collection dates, and two shrub parts. The Spring-Summer experiment consisted of 96 cells representing eight sites, four collection dates, and three shrub parts. Levels of significant variables were compared using Duncan's new multiple range test $(P=.05)$.

\section{Results and Discussion}

\section{Cyanogenesis in Serviceberry}

In order to examine a cross-section of serviceberry shrubs, the experimental sites were selected in a transect that provided a moisture gradient and a transition in vegetation zones. The moisture differences were reflected in both seasonal and annual rainfall records. Seasonal (May to September) records indicated that during this period the average rainfall for McLure was $40 \%$ higher than for Kamloops ${ }^{3}$. Similarly, the average annual precipitation for Barriere, B.C.,situated $17 \mathrm{~km}$ north of McLure, was $44 \mathrm{~cm}$ or $76 \%$ greater than the yearly average for Kamloops (Environment Canada 1975). Within this moisture gradient a vegetation transition occurred with the drier sites $(6,7$, and 8 situated in the ponderosa pine (Pinus ponderosa) zone, and the remainder in the Douglasfir (Pseudotsuga menziesii) zone. Sites 1 to 4 were situated in a Douglasfir-pinegrass (Calamagrostis rubescens) community, Site 5 in a Douglasfir-rough fescue (Festuca scabrella) community, and Sites 6 to 8 in a ponderosa pine rough fescue community.

Ground shrub samples were assayed initially with alkaline picrate paper to test for cyanogenesis. In serviceberry, $\mathrm{HCN}$ will be formed in the simultaneous presence of the endogenous substrate, prunasin, and the endogenous enzymes, $\beta$ glucosidase and hydroxynitrile lyase. The qualitative tests indicated that all the shrub samples were cyanogenic regardless of collection date, site or part. The cyanide potential serviceberry, therefore, persisted throughout the winter in both current and old wood. Despite the climatic variation between sites, acyanogenic forms of serviceberry were not detccted. Cyanogenic polymorphism has been observed in bracken (Pteridium aquilinum), white clover (Trifolium repens), and birdsfoot trefoil (Lotus corniculatus) (CooperDriver and Swain 1976; Jones 1977). Future screening experiments with much larger populations should show whether acyanogenic forms of serviceberry exist.

Replicate determinations were performed to indicate the variability of prunasin concentration within a serviceberry sampling unit. The terminal ends of six lateral branches were collected from the shrub at Site 8 on June 6, 1978. Each branch was separated into current and previous year's woody growth, leaves, and berries, and the subcomposite samples were analyzed for prunasin. Mean prunasin levels (percent dry weight) and $95 \%$ confidence intervals of the mean were as follows: current year's growth, $1.51 \pm 0.59$; previous year's growth, $1.21 \pm 0.24$; leaves, $0.48 \pm 0.09$; and berries $0.24 \pm 0.08$. The degree of variability between

3Personal communication, R.J. Williams, B.C. Ministry of the Environment Kamloops, B.C. branches may point to a relationship between chemical and spatial factors, and whether cyanogenic glycoside gradients occur within a shrub remains to be seen.

A shrub containing $1.5 \%$ prunasin has a cyanide potential of $0.14 \mathrm{~g} \mathrm{HCN} / 100 \mathrm{~g}$ dry matter. Daily doses of $\mathrm{HCN}$ in excess of $10 \mathrm{~g}$ would be considered dangerous for a grazing animal weighing $200 \mathrm{~kg}$ (Radeleff 1970). If the daily consumption rate of the $200 \mathrm{~kg}$ animal is $2.5 \%$ of its body weight or $5 \mathrm{~kg}$ dry matter, the animal could possibly absorb $7.0 \mathrm{~g} \mathrm{HCN}$ from the shrub or just under the dangerous daily dose. Prunasin levels in excess of $1.5 \%$, therefore, could be considered hazardous. However, if the animal is unable to efficiently detoxify the absorbed $\mathrm{HCN}$, the lethal dose is substantially lowered. Previously we reported that mature mule deer expired after consuming serviceberry twigs at the rate of $1 \mathrm{~kg}$ fresh wt/day for a week (Majak et al. 1978). Although the consumption rate was relatively low, (The potential cyanide dose was estimated as $11 \mathrm{mg} \mathrm{HCN} / \mathrm{kg} /$ day) a reduced detoxification rate may have contributed to their demise.

\section{Variation in Prunasin Concentration}

Concentrations of prunasin differed between sites, shrub parts, and collection dates; and there were a number of significant interactions of these factors (Table 1).

Table 1. Analysis of variance for the concentration of prunasin in serviceberry.

\begin{tabular}{llrc}
\hline \hline Experiment & Source & df & $F$ \\
& & & \\
\hline Fall-Winter & site (A) & 7 & $6.35^{* *}$ \\
& part (B) & 1 & $35.88^{* *}$ \\
& date (C) & 6 & $3.01^{*}$ \\
& A $\times$ B & 7 & 0.98 \\
& B $\times$ C & 6 & 0.68 \\
& A $\times$ C & 42 & $1.84^{*}$ \\
Spring-Summer & A & 7 & $3.81^{* *}$ \\
& B & 2 & $167.36^{* *}$ \\
& C' & 3 & $10.72^{* *}$ \\
& A $\times$ B $^{1}$ & 14 & $3.16^{* *}$ \\
& B $\times$ C $^{1}$ & 6 & $3.48^{* *}$ \\
& A $\times$ C $^{1}$ & 21 & $1.82^{*}$
\end{tabular}

$* P<0.05$
$* * P<0.01$

The differences between sites did not appear to be related to zonation. For example, the average prunasin values for Sites 1 and 3 situated in the Douglasfir zone were not significantly different than the averages for Sites 7 and 8 located in the ponderosa pine zone (Fig. 1). The average values for Sites 2 and 5, however, were significantly lower and a common feature shared by these locations was the presence of bog birch (Betula glandulosa), an indicator of substantial ground water. The corollary suggests that moisture stress from lack of ground water could favour the production of higher prunasin levels in serviceberry. Local variations in ground water conditions could explain the significant site $X$ date interactions (Table 1).

Distinct differences in prunasin levels were observed between parts of the shrub (Fig. 2). During the Fall-Winter interval, the average prunasin level in twig segments representing current year's growth was $1.67 \%$ as compared to $1.24 \%$ for prunasin in growth segments from the previous 


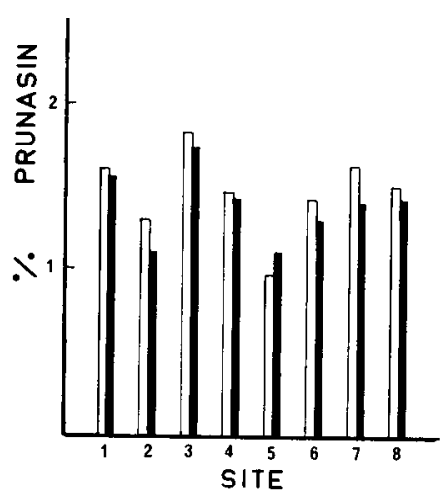

Fig. 1. Mean prunasin concentration in serviceberry at each experimental site during Fall-Winter (open hars) and Spring-Summer (solid bars) periods.

year. Similarly, during the Spring-Summer interval, new wood in 1978 yielded significantly higher prunasin levels (2.27\%) than the 1977 twig growth $(1.35 \%)$, and this was distinctly higher than the average prunasin level in leaves $(0.51 \%)$. Because the shrubs were at different phenological stages, one would expect different rates of prunasin biosynthesis, and this could explain the significant site $X$ part interaction for the Spring-Summer interval (Table 1). The average percentage and range of values (in brackets) of prunasin for various floral and fruit stages were as follows: flower buds, 1.09 (0.73-1.24); blossoms, 0.46 (0.15-0.82); immature berry, 0.30(0.09-0.96); mature berry, $0.22(0.17$ $0.30)$.

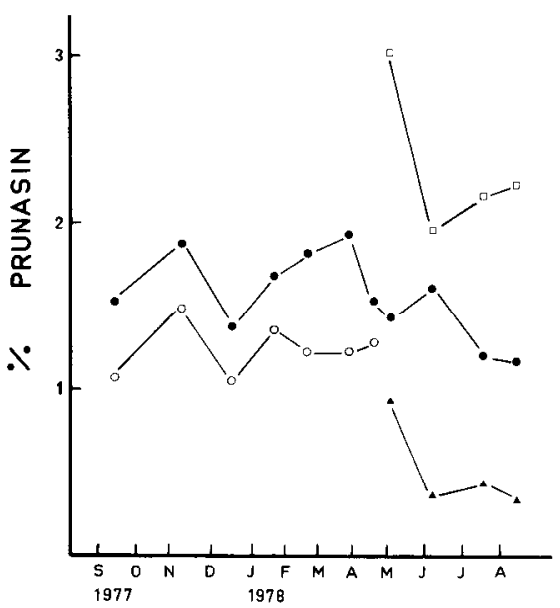

Fig. 2. Mean prunasin concentration for serviceberry leaves and twigs on each collection date. Twigs initiated in 1976 (open circles), 1977 (solid circles), and 1978 (open squares). Leaves initiated in 1978 (triangles).

The most significant changes in prunasin levels occurred in new growth following initiation (Fig. 2). The earlier initiation and the extended growing season in the ponderosa pine zone provided an opportunity to monitor prunasin levels more closely during this critical period. Accordingly, at Sites 6,7 , and 8 dramatic declines in prunasin levels were observed in both new wood and leaves after initiation (Fig. 3 ). The brief interval of high prunasin concentration shown in Figure 3 points to a potentially hazardous period for serviceberry browsers, especially when combined with weather conditions producing a damaging frost and a subsequent rapid release of $\mathrm{HCN}$ during ingestion and thawing in the allimentary tract.

Our preliminary experiments indicate that the prunasin concentration in new growth of chokecherry is considerably

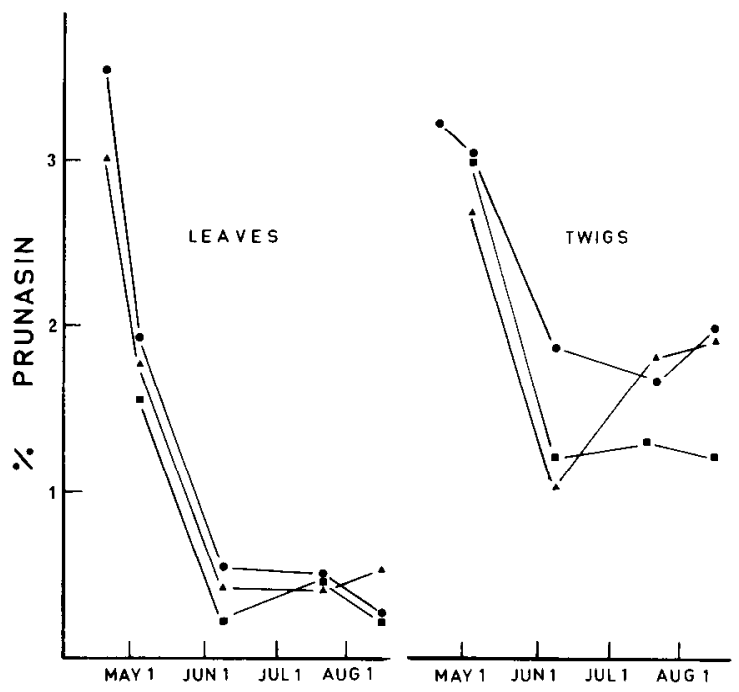

Fig. 3. Prunasin concentration in serviceberry leaves and twigs at sites 6 (squares), 7 (triangels), and 8 (circles) following initiation of growth in 1978.

higher. We obtained levels of $5 \%$ prunasin in leaves and in new twig growth following initiation. Furthermore, elevated prunasin concentrations $(>2.5 \%)$ in leaves were maintained throughout the summer while a steady decline occurred in the prunasin content of new twig growth. Previous year's growth in chokecherry, on the other hand, was similar to serviceberry with prunasin values ranging from 1.2 to $2.2 \%$.

\section{Literature Cited}

Aldridge, W.N. 1944. A new method for the estimation of micro quantities of cyanide or thiocyanate. Analyst 69: 262-265.

Conn, E.E. 1978. Cyanogenesis, the production of hydrogen cyanide by plants. p. 307. : In: Effects of Poisonous Plants on Livestock, R.F. Keeler, K.R. Van Kampen and L.F. James (eds.), Academic Press, New York.

Cooper-Driver, G.A., and T. Swain. 1976. Cyanogenic polymurphism in bracken in relation to herbivore predation. Nature 260: 604

Environment Canada Atmospheric Environment. 1975. Canadian Normals Vol. 2-SI Downsview, Ontario. 333 p.

Garner, R.J. 1967. Veterinary Toxicology. 3rd ed. Baillière, Tindall and Cassell, London. 477 p.

Hitchcock, C.L., and A. Cronquist 1976. Flora of the Pacific Northwest Univ, of Washington Press, Seattle. 730 p.

James, L.F., M.J. Allison, and E.T. Littledike. 1975. Production and modification of toxic substances in the rumen. p. 578. In: Digestion and Metabolism in the Ruminant. I.W. McDonald and A.C.I. Warner (eds.), University of New England, Armidale, Aust.

Jones, D.A. 1977. On the polymorphism of cyanogenesis in Lotus corniculatus L. VII Distribution of the cyanogenic form in Western Europe. Heredity 39: 27-44.

Kufeld, R.C., O.C. Wallmo, and C. Feddema. 1973. Foods of the Rocky Mountain mule deer. U.S. Dep. Agr. Forest Serv. Res. Pap. RM-111. 31 p.

Majak, W., R.J. Bose, and D.A. Quinton. 1978. Prunasin, the cyanogenic glycoside in Amelanchier alnifolia. Phytochemistry 17: 803.

Plummer, A.P., D.R. Christensen, and S.B. Monsen. 1968. Restoring Big Game Range in Utah. Publication No. 68-3, Utah Division of Fish and Game, Ephraim, Utah. 183 p.

Radeleff, R.D. 1970. Veterinary Toxicology 2nd ed. Chap. 4. Lea and Febiger, Philadelphia. 352 p.

Saunders, J.A., and E.E. Conn. 1978. Presence of the cyanogenic glucoside dhurrin in isolated vacuoles from Sorghum. Plant Physiol. 61: 154-157.

Secor, J.B., E.E. Conn, J.E. Dunn, and D.S. Seigler. 1976. Detection and identification of cyanogenic glucosides in six species of Acacia. Phytochemistry 15: 1703-1706.

Willms, W., A. McLean, and R. Ritcey. 1976. Feeding habits of mule deer on fall, winter and spring ranges near Kamloops, British Columbia. Can. J. Anim. Sci. 56: 531-542. 